Rahmatullah et al., Afr J Tradit Complement Altern Med. (2012) 9(3):380-385

Publisher: African Networks on Ethnomedicines

Web page: /http://journals.sfu.ca/africanem/index.php/ajtcam/index

http://dx.doi.org/10.4314/ajtcam.v9i3.12

\title{
MEDICINAL PLANTS USED FOR TREATMENT OF DIABETES BY THE MARAKH SECT OF THE GARO TRIBE LIVING IN MYMENSINGH DISTRICT, BANGLADESH
}

\section{Mohammed Rahmatullah*, Md. Nur Kabidul Azam, Zubaida Khatun, Syeda Seraj, Farhana Islam, Md. Atiqur Rahman, Sharmin Jahan, Md. Shah Aziz}

\author{
Faculty of Life Sciences, University of Development Alternative, \\ Dhanmondi, Dhaka-1205, Bangladesh. \\ *Email: rahamatm@hotmail.com
}

\begin{abstract}
Diabetes mellitus is an endocrinological disorder arising from insulin deficiency or due to ineffectiveness of the insulin produced by the body. This results in high blood glucose and with time, to neurological, cardiovascular, retinal and renal complications. It is a debilitating disease and affects the population of every country of the world. Around 200 million people of the world suffer from this disease and this figure is projected to rise to 300 million in the coming years. The disease cannot be cured with allopathic medicine as the drugs used do not restore normal glucose homeostasis and moreover have side-effects. On the other hand, traditional medicinal practitioners of various countries claim to cure diabetes or at least alleviate the major symptoms and progression of this disease through administration of medicinal plants. The Garos are an indigenous community of Bangladesh, who still follow their traditional medicinal practices. Their traditional medicinal formulations contain a number of plants, which they claim to be active antidiabetic agents. Since observation of indigenous practices have led to discovery of many modern drugs, it was the objective of the present study to conduct a survey among the Marakh sect of the Garos residing in Mymensingh district of Bangladesh to find out the medicinal plants that they use for treatment of diabetes. It was found that the tribal practitioners of the Marakh sect of the Garos use twelve medicinal plants for treatment of diabetes. These plants were Lannea coromandelica, Alstonia scholaris, Catharanthus roseus, Enhydra fluctuans, Terminalia chebula, Coccinia grandis, Momordica charantia, Cuscuta reflexa, Phyllanthus emblica, Syzygium aqueum, Drynaria quercifolia, and Clerodendrum viscosum. A review of the scientific literature demonstrated that almost all the plants used by the Garo tribal practitioners have reported antidiabetic and/or antioxidant properties and have enormous potential for possible development of new and efficacious antidiabetic drugs.
\end{abstract}

Key words: Diabetes, CAM, ethnomedicine, Garo

\section{Introduction}

Diabetes mellitus is a common endocrinological disorder which has reached epidemic proportions among the human population of every country of the world. Around 200 million people of the world are currently suffering from diabetes and the figure is projected to rise to 300 million within 2025 by the World Health Organization. The disease is caused by the inability of pancreas to produce insulin or inability of the body metabolic system to properly use the insulin produced. The causes of this disease are not known; however, it is suspected that occurrences of the disease may result from increased number of elderly people, change in food habits, obesity, and adoption of a sedentary lifestyle. Because the human body cannot properly metabolize sugar when during diabetes, the first symptom of the disease is an increase in blood glucose or hyperglycemia. The impaired metabolism of sugar and other dietary substances like lipids and proteins soon leads to disorders affecting almost all vital organs of the body. In fact, diabetic patients are extremely prone to develop neurological, cardiovascular, retinal and renal complications leading to premature death, which to a lot of extent may be due to diabetes-induced oxidative damages.

Allopathic medicine has no known total cure for this disease, but merely alleviates one or more symptoms, which may lead to delay of development of other complicating factors arising out of the disease. The currently available therapies include regular injection of insulin (which is costly and disliked by most patients), or administration of oral antidiabetic drugs like sulfonylureas, biguanides, $\alpha$-glucosidase inhibitors, and glinides (which may have moderate to serious side-effects) (Nahar, 1993). As a result, there is an intensive interest in the scientific and medical communities for discovery of more efficacious antidiabetic drugs. This interest has focused on the plant kingdom and on traditional medicinal practices, for as has been noted that many modern drugs have been discovered from plants through observation of medicinal practices of indigenous peoples (Balick and Cox, 1996; Gilani and Rahman, 2005). Antidiabetic agents from medicinal plants have been reviewed by Jung et al., (2006).

Bangladesh has a number of indigenous communities or tribes who still rely on their traditional medicinal practitioners for treatment of a diverse variety of ailments. Medicinal plants have throughout centuries formed the mainstay of these tribal practitioners for treatment. Since diabetes affects also the tribal peoples and is recognized as a disease by the practitioners, they use a variety of medicinal plants for treatment of this disease, and claim to completely cure or at least alleviate major symptoms of 
Rahmatullah et al., Afr J Tradit Complement Altern Med. (2012) 9(3):380-385

Publisher: African Networks on Ethnomedicines

Web page: /http://journals.sfu.ca/africanem/index.php/ajtcam/index

http://dx.doi.org/10.4314/ajtcam.v9i3.12

the disease through administration of medicinal plants. We have previously reported that one of the major tribes of Bangladesh, namely the Santals, have medicinal plants for treatment of diabetes (Rahmatullah et al., 2010).

The Garos are an indigenous community residing in the forested regions of the north central districts of Bangladesh. Although in recent years their lifestyle is undergoing drastic changes because of the advent of missionaries and other external factors, to a certain extent they still maintain their indigenous culture, which include language, rituals, and traditional medicinal practices. Since they live in forested regions, since ancient times, their practitioners have developed familiarity and knowledge of medicinal plants found in the vicinity of their forest habitats. The Garos refer to themselves as Mandi or Aa'chik and are divided into four sects - Sangma, Marakh, Momin, and Chatchi. As their traditional medicinal practices and formulations attract even the mainstream population of surrounding villages (who has access to modern allopathic medicine), we decided to conduct an ethnomedicinal survey among the tribal medicinal practitioners of the Marakh sect of the Garo tribe residing in two villages of Mymensingh district, Bangladesh to document their use of medicinal plants for treatment of diabetes. Notably, diabetes is nearing endemic proportions among the population of Bangladesh because of lifestyle changes induced by modernization with consequently developed habits of a carbohydrate-rich diet and sedentary living habits.

\section{Materials and Methods}

The present study was conducted among the tribal medicinal practitioners of the Marakh sect of the Garo tribe-inhabited two villages of Kal Shindu and Monca Para, Dhuba Ura sub-district in Mymensingh district, Bangladesh. The two villages had two traditional practitioners, namely Biresh Marakh Chamukug and Shatish. Both practitioners practiced only Garo traditional medicine based on formulations prepared from medicinal plants. It was initially ascertained that both practitioners recognized diabetes and treated the disease. Diabetes was recognized not on the basis of modern diagnostic procedures. The disease was recognized instead by the appearance of several symptoms like shortness of breath, and frequent thirsts accompanied by frequent urination. The disease was also diagnosed through smelling and tasting the urine of possible patients; the urine of diabetic patients should smell and taste sweet. On occasions, the practitioners would ask the patients to urinate nearby the nest of ants. If a large number of ants hovered around and on the place of urination after the urine has soaked into the soil, then it was decided that the urine had a sweet taste.

Informed consent was initially obtained from both practitioners. The practitioners were mentioned in detail about the purpose of our visit, and consent obtained to disseminate the information both nationally and internationally. Both practitioners, besides speaking the Garo language also were fluent in Bengali, the language spoken by the interviewers. Interviews were conducted with the help of a semi-structured questionnaire and the guided field-walk method of Martin (1995) and Maundu (1995). In this method, the practitioners took the interviewers on guided field-walks through places from where they collected their medicinal plants, pointed out the plants used for treatment of diabetes, and described the formulations and dosages. Plant specimens as pointed by the practitioners were collected from the spot, photographed, dried, and brought to Dhaka for identification. Plant identification was done by Mr. Manjurul Kadir Mia, ex-Curator and Principal Scientific Officer of the Bangladesh National Herbarium at Dhaka.

\section{Results and Discussion}

It was observed that the two practitioners used twelve plants for treatment of diabetes. The plants were distributed into ten families. The twelve plants were Lannea coromandelica, Alstonia scholaris, Catharanthus roseus, Enhydra fluctuans, Terminalia chebula, Coccinia grandis, Momordica charantia, Cuscuta reflexa, Phyllanthus emblica, Syzygium aqueum, Drynaria quercifolia, and Clerodendrum viscosum. The results are shown in Table 1.

The practitioners were observed to use only plant parts in their formulations. Whole plants were not used at all. The various plant parts used were leaves, barks, roots, stems and fruits. Leaves and fruits formed the major plant parts used. Plant parts were usually used singly. However, in two instances, two plant parts from the same plant were combined in the formulation administered. Juice obtained from a crushed mixture of leaves and stems of E. fluctuans was used in one formulation, while juice obtained from a crushed mixture of leaves and roots of $C$. grandis was used in another formulation. In some instances, it was observed that two different plant parts may be used but not used in combination or administered at the same time. For instance, the bark or the root of $L$. coromandelica was used in one formulation. Similarly, diabetic patients were advised to partake of juice obtained from leaves of $M$. charantia or P. emblica in the morning and further advised to eat the fruits in the raw form (Phyllanthus emblica) or in the cooked form (M. charantia) at later times in the day. In all cases except one, a single plant was used for any single formulation. The exception was in the case of $C$. roseus whose leaves were used in combination with leaves of C. viscosum for diabetes treatment.

A review of the existing scientific literature indicated that all the plants used for treatment of diabetes by the Garo practitioners are validated in their uses, based on reported relevant bio-activity. In oral glucose tolerance test, antihyperglycemic activity has been observed with leaves and stems of L. coromandelica in mice (Mannan et al., 2010). It is to be noted that either barks or roots of this plant was observed to be used by the Garo practitioners for treatment of diabetes. Antidiabetic and antihyperlipidemic effect of $A$. scholaris bark has been reported in streptozotocin (STZ)-diabetic rats (Bandawane et al., 2011). The antioxidant potential of crude extracts of E. fluctuans has been confirmed using different in vitro antioxidant models. 
Publisher: African Networks on Ethnomedicines

Web page: /http://journals.sfu.ca/africanem/index.php/ajtcam/index

http://dx.doi.org/10.4314/ajtcam.v9i3.12

Table 1: Medicinal plants used by the Marakh sect of Garo tribal practitioners for treatment of diabetes.

\begin{tabular}{|c|c|c|c|c|c|}
\hline $\begin{array}{c}\text { Serial } \\
\text { Number }\end{array}$ & Scientific Name & Family Name & Local Name & Utilized Part & Formulation \\
\hline 1 & $\begin{array}{l}\text { Lannea coromandelica } \\
\text { (Houtt.) Merr. }\end{array}$ & Anacardiaceae & Jiol bondi & Bark, root & $\begin{array}{l}\text { Barks or roots are soaked in water overnight followed by } \\
\text { taking the water the following morning on an empty stomach. }\end{array}$ \\
\hline 2 & $\begin{array}{l}\text { Alstonia scholaris (L.) } \\
\text { R.Br. }\end{array}$ & Apocynaceae & Chaitan & Leaf & Green leaves are chewed before meals. \\
\hline 3 & $\begin{array}{l}\text { Catharanthus roseus (L.) } \\
\text { G. Don }\end{array}$ & Apocynaceae & Noyon tara & Leaf & $\begin{array}{l}\text { Leaves of Catharanthus roseus and Clerodendrum viscosum } \\
\text { are crushed in water. One teaspoonful of the water is taken } \\
\text { daily before meals. }\end{array}$ \\
\hline 4 & Enhydra fluctuans Lour. & Asteraceae & Helencha & Leaf, stem & $\begin{array}{l}\text { One cup of juice obtained from crushed leaves and stems is } \\
\text { taken orally before meals. }\end{array}$ \\
\hline 5 & Terminalia chebula Retz. & Combretaceae & Hortoki & Fruit & $\begin{array}{l}\text { Fresh fruits are taken daily when in season. Fresh fruits are } \\
\text { also dried when available and when not available, dried fruits } \\
\text { are soaked in water overnight followed by drinking the water } \\
\text { in the morning. }\end{array}$ \\
\hline 6 & $\begin{array}{l}\text { Coccinia grandis (L.) J. } \\
\text { Voigt }\end{array}$ & Cucurbitaceae & Telamon & Leaf, root & $\begin{array}{l}\text { Juice obtained from a crushed mixture of leaves and roots is } \\
\text { taken daily in the morning. }\end{array}$ \\
\hline 7 & Momordica charantia L. & Cucurbitaceae & Usta, Korola & Leaf, fruit & $\begin{array}{l}\text { Half cup of juice obtained from squeezed leaves is taken in } \\
\text { the morning on an empty stomach. Fruits are cooked and } \\
\text { eaten as vegetable during afternoon and evening meals. }\end{array}$ \\
\hline 8 & Cuscuta reflexa Roxb. & Cuscutaceae & Alo lota & Stem & $\begin{array}{l}\text { Half cup of juice obtained from crushed stems is taken in the } \\
\text { morning on an empty stomach. }\end{array}$ \\
\hline 9 & Phyllanthus emblica L. & Euphorbiaceae & Amloki & Leaf, fruit & $\begin{array}{l}\text { One teaspoonful of juice obtained from squeezed leaves is } \\
\text { taken in the morning on an empty stomach. Fruits are chewed } \\
\text { and taken as much as possible. When fresh fruits are not } \\
\text { available, dried fruits are soaked in water and the water is } \\
\text { taken orally with the fruit. }\end{array}$ \\
\hline 10 & $\begin{array}{l}\text { Syzygium aqueum (Burm.f.) } \\
\text { Alston }\end{array}$ & Myrtaceae & Jamrul & Fruit & $\begin{array}{l}\text { Fruits are taken orally when in season. They can be taken any } \\
\text { time before or after meals. }\end{array}$ \\
\hline 11 & $\begin{array}{l}\text { Drynaria quercifolia (L.) J. } \\
\text { Smith }\end{array}$ & Polypodiaceae & Bandor shoal & Stem & $\begin{array}{l}\text { Two teaspoonful of juice obtained from crushed stem is taken } \\
\text { daily. }\end{array}$ \\
\hline 12 & $\begin{array}{l}\text { Clerodendrum viscosum } \\
\text { Vent. }\end{array}$ & Verbenaceae & Baik pata & Leaf & $\begin{array}{l}\text { Leaves of Catharanthus roseus and Clerodendrum viscosum } \\
\text { are crushed in water. One teaspoonful of the water is taken } \\
\text { daily before meals. }\end{array}$ \\
\hline
\end{tabular}


Rahmatullah et al., Afr J Tradit Complement Altern Med. (2012) 9(3):380-385

Publisher: African Networks on Ethnomedicines

Web page: /http://journals.sfu.ca/africanem/index.php/ajtcam/index

http://dx.doi.org/10.4314/ajtcam.v9i3.12

Additionally, polyphenolic compounds, which have been shown in various assays to have free radical scavenging activity has been reported from this plant (Sannigrahi et al., 2010). Since free radicals are linked with various diseases including diabetes and cardiovascular disorders, free radical scavenging and antioxidant activities can play a major role in ameliorating the progression of diabetes-induced complications.

Leaf extract of C. roseus reportedly lowered blood sugar in STZ-diabetic rats (Chattopadhyay, 1999). Hypoglycemic activity has also been reported for dichloromethane-methanol extract of stems and twigs of the plant in STZ-diabetic rats (Singh et al., 2001). The extract reportedly improved enzymic activities of glycogen synthase, glucose 6-phosphate dehydrogenase, succinate dehydrogenase and malate dehydrogenase in liver of diabetic animals. Juice of fresh leaves of the plant was observed to reduce blood glucose in normal and alloxan diabetic rabbits (Nammi et al., 2003). Extract of the plant also stimulated glucose utilization in hepatocytes (van de Venter et al., 2008). Ethanolic extract of the plant lowered blood glucose levels in oral glucose tolerance tests in glucose induced hyperglycemic rats (Islam et al., 2009). Antihyperglycemic activity has been reported following administration of leaf powder in STZ-diabetic rats (Rasineni et al., 2010). Inhibition of aldose reductase (a key enzyme in cataractogenesis) as well as free radical scavenging activity was reported for the plant extract, suggesting that administration of the extract can delay diabetes-induced cataract formation (Gacche and Dhole, 2011).

The chloroform extract of $T$. chebula has been shown to demonstrate antidiabetic and renoprotective effects in STZdiabetic rats (Rao and Nammi, 2006). Aqueous extract of fruits, when administered daily once for 2 months showed reversals of elevated blood glucose, glycosylated hemoglobin (HbAlc), and lipids as well as decreased serum insulin levels in STZ-diabetic rats, indicating the potential of fruits in treatment of diabetes (Murali et al., 2007). Methanolic extract containing 2.7\% chebulic acid prevented formation of advanced glycation end products and endothelial cell dysfunction, which strongly indicates that the extract may be of potential use in alleviating diabetes-related complications (Lee et al., 2011). The antioxidant effect of leaves of C. grandis (another plant part used by the Garo practitioners for treatment of diabetes) has been shown in vitro, which has been attributed to presence of phenolic and flavonoid compounds in leaf extracts (Umamaheswari and Chatterjee, 2007).

Cucurbitane triterpenoids, isolated from M. charantia, reportedly stimulated GLUT4 translocation to cell membrane, an essential step for glucose entry into cells. They also increased activity of AMP-activated protein kinase, which plays a key role in mediating glucose uptake and fatty acid oxidation. Moreover, they enhanced glucose disposal in glucose tolerance tests in both insulin-sensitive and insulin-resistant mice, and displayed insulin secretion activity. Taken together, the results indicate a therapeutic value of these compounds for diabetes and obesity (Tan et al., 2008; Ma et al., 2010). A saponin fraction isolated from fruits reportedly showed hypoglycemic activity in alloxan diabetic mice (Han et al., 2008). Administration of alcoholic extract of whole fruit powder to alloxan diabetic albino rats has been shown to result in decreases in blood sugar and improvements in the islets of Langerhans (Singh et al., 2008). Administration of fruit extract to sucrose-loaded alloxan diabetic rats normalized glucose levels and reduced triglyceride and low-density lipoprotein levels while increasing high-density lipoprotein levels and prevented oxidative stress, indicating a beneficial effect both on diabetes and reduced chances of diabetes leading to cardiovascular disorders (Chaturvedi and George, 2010). Antidiabetic effect of fruit extract has also been reported for insulin-resistant $\mathrm{db} / \mathrm{db}$ mice (Klomann et al., 2010). Lyophilized fruit juice reportedly showed neuroprotective effect in global cerebral ischemia and reperfusion induced neuronal injury in diabetic mice (Malik et al., 2011). Fruit extract has further been shown (when administered to STZ-induced neonatal diabetic rats) to reduce blood glucose level, increase serum insulin level, and both alleviated pancreatic damage and increased the number of $\beta$-cells in pancreas (Abdollahi et al., 2011). That administration of extract of fruits of $M$. charantia can positively modulate pancreatic $\beta$-cells through increasing size, area and number, as well as decrease serum glucose and increase serum insulin concentrations has been corroborated in another study on neonatal STZdiabetic rats (Hafizur et al., 2011). The reported scientific results validate the use of $M$. charantia leaves and fruits for treatment of diabetes by the Garo medicinal practitioners.

The stems of C. reflexa have also been reported to have hypoglycemic properties (Rahmatullah et al., 2009). The leaves and fruits of $P$. emblica were used by the Garo practitioners as anitidiabetic treatment. Pericarp of fruits of the plant and enriched tannoid fraction has been shown to delay STZ-induced diabetic cataract in rats (Suryanarayana et al., 2007). Fruit extract has been shown to have free radical scavenging activity and antioxidant potential. Fruit extract also inhibited $\alpha$-amylase and $\alpha$ glucosidase, two key enzymes linked to type 2 diabetes (Nampoothiri et al., 2011). S. aqueum has no reported antihyperglycemic activity. However, antihyperglycemic flavonoids have been reported from a related plant, Syzygium samarangense (Resurreccion-Magno et al., 2005). Antioxidant properties has been reported for D. quercifolia and C. viscosum extracts (Lai and Lim, 2011; Prakash et al., 2011).

Taken together, practically all the medicinal plants or plant parts used by the Garo practitioners for treatment of diabetes can be validated in their traditional uses directly through scientific evidence of their antidiabetic properties or their antioxidant properties, the latter having a beneficial effect in ameliorating diabetes-induced various complications affecting other organs of the body. Type 2 diabetes has been reported to lead to increased production of free radicals and a probable reduction in plasma antioxidants; under such circumstances antioxidants or free radical scavengers may not only be beneficial but also play a major role in even reversal of diabetes-induced damages (Illison et al., 2011; Gorąca et al., 2011). As such, the antidiabetic medicinal plants of the Garo tribal practitioners warrant detailed scientific studies in the search for newer and more efficacious antidiabetic drugs. Particularly promising are plants like C. roseus, T. chebula, M. charantia, and P. emblica. 
Publisher: African Networks on Ethnomedicines

Web page: /http://journals.sfu.ca/africanem/index.php/ajtcam/index

http://dx.doi.org/10.4314/ajtcam.v9i3.12

\section{References}

1. Abdollahi, M., Zuki, A.B., Goh, Y.M., Rezaeizadeh, A., and Noordin, M.M. (2011). Effects of Momordica charantia on pancreatic histopathological changes associated with streptozotocin-induced diabetes in neonatal rats. Histology and Histopathology. 26:13-21.

2. Balick, J.M., and Cox, P.A. (1996). Plants, People and Culture: the Science of Ethnobotany, Scientific American Library, New York.

3. Bandawane, D., Juvekar, A., and Juvekar, M. (2011). Antidiabetic and antihyperlipidemic effect of Alstonia scholaris Linn bark in streptozotocin induced diabetic rats. Indian Journal of Pharmaceutical Education and Research. 45:114120.

4. Chattopadhyay, R.R. (1999). A comparative evaluation of some blood sugar lowering agents of plant origin. Journal of Ethnopharmacology. 67:367-372.

5. Chaturvedi, P., and George, S. (2010). Momordica charantia maintains normal glucose levels and lipid profiles and prevents oxidative stress in diabetic rats subjected to chronic sucrose load. Journal of Medicinal Food. 13:520-527.

6. Gacche, R.N., and Dhole, N.A. (2011). Profile of aldose reductase inhibition, anti-cataract and free radical scavenging activity of selected medicinal plants: an attempt to standardize the botanicals for amelioration of diabetes complications. Food and Chemical Toxicology. 49:1806-1813.

7. Gilani, A.H., and Rahman, A.U. (2005). Trends in ethnopharmacology. Journal of Ethnopharmacology. 100:43-49.

8. Gorąca, A., Huk-Kolega, H., Piechota, A., Kleniewska, P., Ciejka, E., and Skibska, B. (2011). Lipoic acid - biological activity and therapeutic potential. Pharmacological Reports. 63:849-858.

9. Hafizur, R.M., Kabir, N., and Chisti, S. (2011). Modulation of pancreatic $\beta$-cells in neonatally streptozotocin-induced type 2 diabetic rats by the ethanolic extract of Momordica charantia fruit pulp. Natural Product Research. 25:353-367.

10. Han, C., Hui, Q., and Wang, Y. (2008). Hypoglycaemic activity of saponin fraction extracted from Momordica charantia in PEG/salt aqueous two-phase systems. Natural Product Research. 22:1112-1119.

11. Illison, V.K., Rondó, P.H., de Oliveira, A.M., D Abronzo, F.H., and Campos, K.F. (2011). The relationship between plasma $\alpha$-tocopherol concentration and vitamin $\mathrm{E}$ intake in patients with Type 2 diabetes mellitus. International Journal for Vitamin and Nutrition Research. 81:12-20.

12. Islam, M.A., Akhtar, M.A., Khan, M.R., Hossain, M.S., Alam, A.H., Ibne-Wahed, M.I., Amran, M.S., Rahman, B.M., and Ahmed, M. (2009). Oral glucose tolerance test (OGTT) in normal control and glucose induced hyperglycemic rats with Coccinia cordifolia L. and Catharanthus roseus L. Pakistan Journal of Pharmaceutical Sciences. 22:402-404.

13. Jung, M., Park, M., Lee, H.C., Kang, Y.-H., Kang, E.S., and Kim, S.K. (2006). Antidiabetic agents from medicinal plants. Current Medicinal Chemistry. 13:1203-1218.

14. Klomann, S.D., Mueller, A.S., Pallauf, J., and Krawinkel, M.B. (2010). Antidiabetic effects of bitter gourd extracts in insulin-resistant $\mathrm{db} / \mathrm{db}$ mice. British Journal of Nutrition. 104:1613-1620.

15. Lai, H.-Y., and Lim, Y.-Y. (2011). Antioxidant properties of some Malaysian ferns. $3^{\text {rd }}$ International Conference on Chemical, Biological and Environmental Engineering. IPCBEE, vol. 20, IACSIT Press, Singapore.

16. Lee, H.S., Cho, H.Y., Park, K.W., Kim, I.H., Kim, J.T., Nam, M.H., and Lee, K.W. (2011). Inhibitory effects of Terminalia chebula extract on glycation and endothelial cell adhesion. Planta Medica. 77:1060-1067.

17. Ma, J., Whittaker, P., Keller, A.C., Mazzola, E.P., Pawar, R.S., White, K.D., Callahan, J.H., Kennelly, E.J., Krynitsky, A.J., and Rader, J.I. (2010). Cucurbitane-type triterpenoids from Momordica charantia. Planta Medica. 76:1758-1761.

18. Malik, Z.A., Singh, M., and Sharma, P.L. (2011). Neuroprotective effect of Momordica charantia in global cerebral ischemia and reperfusion induced neuronal damage in diabetic mice. Journal of Ethnopharmacology. 133:729-734.

19. Mannan, A., Das, H., Rahman, M., Jesmin, J., Siddika, A., Rahman, M., Rahman, S., Chowdhury, M.H., and Rahmatullah, M. (2010). Antihyperglycemic activity evaluation of Leucas aspera (Willd.) Link leaf and stem and Lannea coromandelica (Houtt.) Merr. bark extract in mice. Advances in Natural and Applied Sciences. 4:385-388.

20. Martin, G.J. (1995). Ethnobotany: a 'People and Plants' Conservation Manual, Chapman and Hall, London.

21. Maundu, P. (1995). Methodology for collecting and sharing indigenous knowledge: a case study. Indigenous Knowledge and Development Monitor. 3:3-5.

22. Murali, Y.K., Anand, P., Tandon, V., Singh, R., Chandra, R., and Murthy, P.S. (2007). Long-term effects of Terminalia chebula Retz. on hyperglycemia and associated hyperlipidemia, tissue glycogen content and in vitro release of insulin in streptozotocin induced diabetic rats. Experimental and Clinical Endocrinology \& Diabetes. 115:641-646.

23. Nahar, N. (1993). Traditional Medicine, Edn. 18, Oxford and OBH Publishing Co. Pvt. Ltd., New Delhi, 205-209.

24. Nammi, S., Boini, M.K., Lodagala, S.D., and Behara, R.B. (2003). The juice of fresh leaves of Catharanthus roseus Linn. reduces blood glucose in normal and alloxan diabetic rabbits. BioMed Central Complementary and Alternative Medicine. 3:4. 
Rahmatullah et al., Afr J Tradit Complement Altern Med. (2012) 9(3):380-385

Publisher: African Networks on Ethnomedicines

Web page: /http://journals.sfu.ca/africanem/index.php/ajtcam/index

http://dx.doi.org/10.4314/ajtcam.v9i3.12

25. Nampoothiri, S.V., Prathapan, A., Cherian, O.L., Raghu, K.G., Venugopalan, V.V., and Sundaresan, A. (2011). In vitro antioxidant and inhibitory potential of Terminalia bellerica and Emblica officinalis fruits against LDL oxidation and key enzymes linked to type 2 diabetes. Food and Chemical Toxicology. 49:125-131.

26. Prakash, G., Rajalakshmi, V., Thirumoorthy, N., Ramasamy, P., and Selvaraj, S. (2011). Antioxidant activity of ethanolic extracts of Clerodendrum viscosum Vent and Biophytum condolleanum Wight. Der Pharmacia Lettre. 3:248251.

27. Rahmatullah, M., Sultan, S., Toma, T.T., Lucky, S.A., Chowdhury, M.H., Haque, W.M., Annay, E.A., and Jahan, R. (2009). Effect of Cuscuta reflexa stem and Calotropis procera leaf extracts on glucose tolerance in glucose-induced hyperglycemic rats and mice. African Journal of Traditional, Complementary, and Alternative Medicines. 7:109-112.

28. Rahmatullah, M., Mollik, A.H., Rahman, S., Hasan, N., Agarwala, B., and Jahan, R. (2010). A medicinal plant study of the Santal tribe in Rangpur district, Bangladesh. Journal of Alternative and Complementary Medicine. 16:419-425.

29. Rao, N.K., and Nammi, S. (2006). Antidiabetic and renoprotective effects of the chloroform extract of Terminalia chebula Retz. seeds in streptozotocin-induced diabetic rats. BioMed Central Complementary and Alternative Medicine. 6:17.

30. Rasineni, K., Bellamkonda, R., Singareddy, S.R., and Desireddy, S. (2010). Antihyperglycemic activity of Catharanthus roseus leaf powder in streptozotocin-induced diabetic rats. Pharmacognosy Research. 2:195-201.

31. Resurreccion-Magno, M.H., Villaseñor, I.M., Harada, N., and Monde, K. (2005). Antihyperglycaemic flavonoids from Syzygium samarangense (Blume) Merr. and Perry. Phytotherapy Research. 19:246-251.

32. Sannigrahi, S., Mazuder, U.K., Pal, D.K., Parida, S., and Jain, S. (2010). Antioxidant potential of crude extract and different fractions of Enhydra fluctuans Lour. Indian Journal of Pharmaceutical Research. 9:75-82.

33. Singh, S.N., Vats, P., Suri, S., Shyam, R., Kumria, M.M., Ranganathan, S., and Sridharan, K. (2001). Effect of an antidiabetic extract of Catharanthus roseus on enzymic activities in streptozotocin induced diabetic rats. Journal of Ethnopharmacology. 76:269-277.

34. Singh, N., Gupta, M., Sirohi, P., and Varsha. (2008). Effects of alcoholic extract of Momordica charantia (Linn.) whole fruit powder on the pancreatic islets of alloxan diabetic albino rats. Journal of Environmental Biology. 29:101106.

35. Suryanarayana, P., Saraswat, M., Petrash, J.M., and Reddy, G.B. (2007). Emblica officinalis and its enriched tannoids delay streptozotocin-induced diabetic cataract in rats. Molecular Vision. 13:1291-1297.

36. Tan, M.J., Ye, J.M., Turner, N., Hohnen-Behrens, C., Ke, C.Q., Tang, C.P., Chen, T., Weiss, H.C., Gesing, E.R., Rowland, A., James, D.E., and Ye, Y. (2008). Antidiabetic activities of triterpenoids isolated from bitter melon associated with activation of the AMPK pathway. Chemistry \& Biology. 15:263-273.

37. Umamaheswari, M., and Chatterjee, T.K. (2007). In vitro antioxidant activities of the fractions of Coccinia grandis L. leaf extract. African Journal of Traditional, Complementary, and Alternative Medicines. 5:61-73.

38. van deVenter, M., Roux, S., Bungu, L.C., Louw, J., Crouch, N.R., Grace, O.M., Maharaj, V., Pillay, P., Sewnarian, P., Bhagwandin, N., and Folb, P. (2008). Antidiabetic screening and scoring of 11 plants traditionally used in South Africa. Journal of Ethnopharmacology. 119:81-86. 